\title{
Screening of recombinant inbred lines for salinity tolerance in bread wheat (Triticum aestivum L.)
}

\author{
Amin Azadi ${ }^{1 \star}$, Eslam Majidi Hervan², Seyed Abolghasem Mohammadi ${ }^{3}$, Foad Moradi ${ }^{2}$, Babak \\ Nakhoda $^{2}$, Mojtaba Vahabzade ${ }^{4}$ and Mohsen Mardi ${ }^{5}$ \\ ${ }^{1}$ Department of Plant breeding, Science and Research Branch, Islamic Azad University, Tehran, Iran. \\ ${ }^{2}$ Department of Molecular Physiology, Agricultural Biotechnology Research Institute of Iran (ABRII), Karaj, Iran. \\ ${ }^{3}$ Department of Agronomy and Plant Breeding, Faculty of Agriculture, Tabriz University, Tabriz, Iran. \\ ${ }^{4}$ Seed and Plant Improvement Institute, Karaj, Iran. \\ ${ }^{5}$ Department of Genomics, Agricultural Biotechnology Research Institute of Iran (ABRII), Karaj, Iran.
}

Accepted 8 August, 2011

\begin{abstract}
Screening and increasing of salinity tolerance of crops is an important aim of many plant breeders. Screening a large number of plants for salinity tolerance is not easy, therefore this investigation was performed to evaluate and screen $186 \mathrm{~F}_{8}$ recombinant inbred lines (RILs) derived from a cross between Superhead\#2 (Super Seri) and Roshan wheat varieties for salinity tolerance. All the individuals were evaluated under two treatments including control $(10 \mathrm{mM} \mathrm{NaCl})$ and salt stress $(150 \mathrm{mM} \mathrm{NaCl})$. Different traits relating to salt tolerance, including dry matter of shoot and root, sodium and potassium concentration, chlorophyll content and relative water content (RWC) were measured. Significant differences were observed among wheat RILs for all the measured traits. Seedling growth was reduced by salinity in all RILs and we observed a significant negative correlation between shoot dry matter and sodium concentration $\left(r=-0.52^{\star \star}\right)$, whereas significant positive correlations between shoot dry matter and $\mathrm{K}^{+} / \mathrm{Na}^{+}$ratio $\left(r=0.36^{\star \star}\right)$, chlorophyll content $\left(r=0.20^{\star \star}\right)$ and $\mathrm{RWC}\left(r=0.39^{\star \star}\right)$ were detected. Based on our results, sodium concentration of leaf, $\mathrm{K}^{+} / \mathrm{Na}^{+}$ratio, chlorophyll content and $\mathrm{RWC}$ are good indexes for screening bread wheat genotypes for salinity tolerance.
\end{abstract}

Key words: Screening, salinity tolerance, recombinant inbred lines, wheat.

\section{INTRODUCTION}

Wheat is one of the most important food crops in the word. It is the only staple food in many countries; therefore, its productivity directly affects human survival and quality of life (Ma et al., 2007). Obtaining high yield is the aim of most researchers and it is becoming increasingly difficult to ignore yield restricted agents, such as biotic and abiotic stresses. Salinity is an important abiotic stress that limits productivity of crops all over the world. In arid and semiarid regions, where rainfall is insufficient to leach soluble substances from the soil, or where drainage is restricted, soils with high concentration

*Corresponding author. E-mail: azadi.amin@gmail.com.

Abbreviations: RILs, Recombinant inbred lines; RWC, relative water content; ST, salinity tolerance. of salt (salt-affected soils) may be formed (FAO, 2005).

Salt-affected soil occur in more than 100 countries of the world with a variety of extent, nature and properties (Rengasamy, 2006) and about $20 \%$ of agricultural land in the world are affected by soils salinity (Flowers and Yeo, 1995). The global cost of irrigation-induce salinity is equivalent to an estimated US $\$ 11$ billion per year (FAO, 2005). Three general categories of salt affected soils have been identified with USDA salinity laboratory: salinity, sodicity and alkalinity (Ussl, 2005). Cations and anions that accumulate in these soils include $\mathrm{Na}^{+}, \mathrm{K}^{+}$, $\mathrm{Mg}^{+2}, \mathrm{Ca}^{+2}, \mathrm{Cl}^{-}, \mathrm{So}_{4}^{-2}, \mathrm{CO}_{3}^{-2}$ and $\mathrm{HCO}_{3}^{-}(\mathrm{FAO}, 2000)$. Of these, chlorides, sulphates and bicarbonates of sodium, calcium and magnesium frequently occur in saline soil and irrigation water (Khan et al., 2001).

A considerable number of literatures have been published on screening methods in salinity tolerance in wheat (Munns and James, 2003), rice (Gregorio et al., 
1997), alfalfa (Peel et al., 2004), tomatoes (Dasgan et al., 2002), barley (Chen et al., 2005) potato (Shaterian et al., 2008), and on physiology and mechanism of salinity tolerance (Sairam and Tyagi, 2004; Munns, 2005; Munns and Tester, 2008; Bartels and Sunkars, 2005; Møller and Tester, 2007; Mahajan and Tuteja, 2005; Neumann, 1997). Many researchers have shown relationship between $\mathrm{Na}^{+}$exclusion and salinity tolerance in wheat (Garcia et al., 1995; Ashraf and O'Leary, 1996; Munns et al., 2006; Munns and James, 2003), but some researchers did not find any correlation for $\mathrm{Na}^{+}$exclusion and salinity tolerance (ST) in bread wheat (Genc et al., 2007) or in certain subspecies of tetraploid wheat Triticum turgidum (Munns and James, 2003). In rice, $\mathrm{K}^{+} / \mathrm{Na}^{+}$ discrimination recorded in the stressed plants was significantly correlated with the surviving percentages recorded (Zhu et al., 2001), and it is conclusively another good index of salinity tolerance in bread wheat (Ashraf and O'Leary, 1996; Din et al., 2008; Dubcovsky et al.,1996; Pritchard et al., 2002) or rice (Asch et al., 2000). But in certain subspecies of durum wheat, $\mathrm{K}^{+} / \mathrm{Na}^{+}$ discrimination correlated to salinity tolerance in a lesser degree (Munns and James, 2003) or correlated in a good degree (Munns et al., 2000). The low leaf $\mathrm{Na}$ and high leaf $\mathrm{K}$ concentrations characteristic of the enhanced $\mathrm{K} / \mathrm{Na}$ discrimination character, originally found in Aegilops squarrosa and in hexaploid wheat, were also found in other Aegilops species containing the D genome, but not in Aegilops ventricosa and the $\mathrm{S}$ genome diploid Aegilops species (section Sitopsis); all lacked the enhanced $\mathrm{K}^{+} / \mathrm{Na}^{+}$discrimination trait (Gorham, 1989).

Relative water content (RWC) has been widely accepted as a reproducible and meaningful index of plant water status (Smart, 1974). It has been demonstrated that salt stress also affected and decreased RWC (Vysotskaya et al., 2010) but Sohail et al. (2009) showed that increasing salt concentrations also led to a significant increase in relative water contents of leaf and root tissues.

Salt tolerance selection method has been performed in hydroponics or field, however screening method based on hydroponics or supported hydroponics have become the preferred method for most researchers, because it gives a high degree of control and reproducibility (Genc et al., 2007). The advantages of field screening are that space is not a major limiting factor to replication and population sizes, and the environmental conditions are almost what will be encountered under real field conditions (Shannon, 1997).

The aim of this study was to evaluate and screen the recombinant inbred lines (RILs) for salinity tolerance in wheat in control system.

\section{MATERIALS AND METHODS}

$186 \mathrm{~F}_{8}$ RILs derived from a cross between Superhead\#2 (Super seri) (high yielding and salt sensitive variety from SPII shown with $P_{1}$ ) and Roshan (a local salt tolerance cultivar shown with $P_{2}$ ) via single seed descent were used in this study.

This experiment was carried out in split plot with a randomized complete block design in a glasshouse (16/8, day/night photoperiod, $27 / 20^{\circ} \mathrm{C}$ temperature and minimum relative humidity of about $60 \%$ ) at the Agricultural Biotechnology Research Institute of Iran (ABRII) with hydroponic. The main plots were salt stress with two levels (10 and $150 \mathrm{mM}$ ) and sub plots were wheat genotypes including 186 RILs in three replications (five seedlings per replicate).

Selected seeds were sterilized (1\% hypochlorite for $15 \mathrm{~min}$ ) and germinated in Petri dishes according to Munns and James (2003). After three days, the uniformly germinated seeds were transferred to holes made in sheets of $2 \mathrm{~cm}$ styrofoam, which were floated on a half-strength Hoagland solution (Hoagland and Arnon,1950) for two days (Hoagland materials from Duchefa Biochemie, Netherlands).

Then, full-strength Hoagland solution was applied for two days. After four days of transfer, salt treatment started, to avoid salt shock, $50 \mathrm{mM} \mathrm{NaCl}$ was added daily to a final concentration of 150 $\mathrm{mM}$. The $\mathrm{pH}$ was monitored daily with $\mathrm{pH}$ meter $(\mathrm{HI}$ 991001, RoTH, Germany) and adjusted to 5.5 to 6.0 using either $\mathrm{HCl}$ or $\mathrm{NaOH}$. Nutrient solution was changed every seven days.

\section{Measuring traits and chemical analysis}

The third leaf of each RIL after two weeks were harvested, weighed, rinsed with deionized water, then dried $\left(48 \mathrm{~h}, 72^{\circ} \mathrm{C}\right)$, weighed again and $0.1 \mathrm{~g}$ of each RIL was extracted in $0.1 \mathrm{M}$ acetic acid at $80^{\circ} \mathrm{C}$ for $2 \mathrm{~h}$ and analyzed for $\mathrm{Na}^{+}$and $\mathrm{K}^{+}$by flame photometer (410, Corning M410, U.K). After three weeks treatment of $150 \mathrm{mM} \mathrm{NaCl}$, the chlorophyll content of base, middle and tip (Munns and James, 2003) of the third leaves was measured using a SPAD-502 chlorophyll meter (Minolta, Japan). Each RIL was measured nine times in each replicate. RWC was measured using the third leaves after three weeks salinity treatment. Immediately after cutting at the base of lamina, fresh weights were determined quickly (less than $1 \mathrm{~h}$ ). Then, leaves were soaked in distilled water at room temperature and under the low light condition. After $4 \mathrm{~h}$, the samples were taken out of distilled water and were well dried lightly for any surface moisture with filter paper and immediately weighed to obtain turgid weight. Dry weights were obtained after oven drying of the leaves $\left(48 \mathrm{~h}, 72^{\circ} \mathrm{C}\right)$ then RWC was calculated according to the equation of Barrs and Weatherly (1962):

RWC $(\%)=$ (fresh weight - dry weight) / (turgid weight - dry weight) $\times 100$

At the end of the third weeks, whole shoot and root of each RILs was harvested separately, weighed and oven dried $\left(48 \mathrm{~h}, 72^{\circ} \mathrm{C}\right)$ for dry weight.

\section{Data analysis}

Data from the experiment were tested with Kolmogorov-smirnov test for non-normality. ANOVA and mean comparison (Duncan's method with $p=0.01$ ) were done using MSTATC statistical package version 2.10. Pearson correlation analysis was performed using Excel. Salinity tolerance was calculated as shoot dry weight as a percentage of the control shoot dry weight (Munns and James, 2003).

\section{RESULTS}

Data from all measurement showed normal distribution. 
Table 1. Analysis of variance for traits investigated in the 186 RILs in response to salinity stress.

\begin{tabular}{|c|c|c|c|c|c|c|c|c|c|c|}
\hline \multirow{2}{*}{$\begin{array}{l}\text { Source of } \\
\text { variation }\end{array}$} & \multirow{2}{*}{ Df } & \multicolumn{9}{|c|}{ Mean square } \\
\hline & & $\mathrm{FWS}^{1}$ & FWR $^{2}$ & $\mathrm{DWS}^{3}$ & $\mathrm{DWR}^{4}$ & $\mathrm{Na}^{5}$ & $\mathrm{~K}^{6}$ & $\mathrm{~K} / \mathrm{Na}^{7}$ & Chlo $^{8}$ & RWC $^{9}$ \\
\hline Block & 2 & 143.01 & 8.34 & 0.473 & 3.562 & 6.24 & 0.91 & 2944.64 & 5093.8 & 98.78 \\
\hline Salinity & 1 & $934.60^{*}$ & $5.28^{*}$ & $3.111^{*}$ & $21.378^{*}$ & $805.75^{\star *}$ & $505.97^{*}$ & $10872.7^{\star}$ & $123411.4^{*}$ & $528.8^{*}$ \\
\hline Error & 2 & 33.94 & 0.189 & 0.041 & 0.386 & 7.04 & 23.12 & 483.25 & 2853.88 & 10.78 \\
\hline RILs & 185 & $2.18^{\star \star *}$ & $0.248^{* * *}$ & $0.021^{* * *}$ & $0.010^{* * *}$ & $3.47^{\star \star \star}$ & $1.95^{\star * \star}$ & $3001.16^{\star * *}$ & $453.54^{* \star *}$ & $200.1^{* * *}$ \\
\hline Salinity* RILs & 185 & $1.45^{\star \star \star}$ & $0.174^{* * *}$ & $0.014^{\star * *}$ & $0.007^{* * *}$ & $1.88^{\star * *}$ & $0.097^{* * *}$ & $227.007^{\star \star *}$ & $37.66^{\star * *}$ & $122.7^{* * *}$ \\
\hline Error & 740 & 0.065 & 0.007 & 0.0002 & 0.0018 & 0.015 & 0.011 & 10.13 & 1.21 & 10.54 \\
\hline CV\% & & 13.49 & 19.02 & 8.69 & 34.41 & 11.001 & 7.46 & 27.16 & 3.01 & 4.37 \\
\hline
\end{tabular}

*Significant at $\mathrm{P}<0.05$ level; ${ }^{* *}$ significant at $\mathrm{P}<0.01$ level; ${ }^{* * *}$ significant at $\mathrm{P}<0.001$ level. ${ }^{1}$ Fresh weight of shoot; ${ }^{2}$ fresh weight of root; ${ }^{3}$ dry weight of shoot; ${ }^{4}$ dry weight of root; ${ }^{5} \mathrm{Na}$ concentration; ${ }^{6} \mathrm{~K}$ concentration; ${ }^{7} \mathrm{~K} / \mathrm{Na}$ ratio; ${ }^{8}$ chlorophyll content; ${ }^{9}$ relative water content.

Table 2. Means ( \pm standard error) for traits of parents and $186 \mathrm{~F}_{8} \mathrm{RILs}$ grown at 10 (control) and $150 \mathrm{mM} \mathrm{NaCl}$.

\begin{tabular}{|c|c|c|c|c|c|c|c|c|c|}
\hline Parameter & FWS $^{1}$ & FWR $^{2}$ & DWS $^{3}$ & DWR $^{4}$ & $\mathrm{Na}^{5}$ & $\mathbf{K}^{6}$ & $\mathrm{~K} / \mathrm{Na}^{7}$ & $\mathrm{Chlo}^{8}$ & RWC $^{9}$ \\
\hline \multicolumn{10}{|l|}{ Control } \\
\hline Roshan & $1.985 \pm 0.05$ & $0.45 \pm 0.003$ & $0.199 \pm 0.012$ & $0.017 \pm 0.07$ & $0.40 \pm 0.32$ & $3.56 \pm 0.16$ & $8.90 \pm 0.96$ & $38.02 \pm 0.23$ & $83.8 \pm 0.5$ \\
\hline $\begin{array}{l}\text { Super } \\
\text { Head\#2 }\end{array}$ & $2.57 \pm 0.01$ & $0.535 \pm 0.12$ & $0.235 \pm 0.54$ & $0.029 \pm .001$ & $0.78 \pm 0.18$ & $2.88 \pm 0.03$ & $3.69 \pm 0.69$ & $30.76 \pm 1.50$ & $82.0 \pm 0.3$ \\
\hline $\mathrm{F}_{8} \mathrm{RILs}$ & $2.55 \pm 0.06$ & $0.478 \pm 0.01$ & $0.231 \pm 0.006$ & $0.02 \pm 0.001$ & $0.283 \pm 0.01$ & $1.68 \pm 0.05$ & $20.52 \pm 2.94$ & $47.32 \pm 0.82$ & $80.0 \pm 0.6$ \\
\hline \multicolumn{10}{|c|}{$150 \mathrm{mM} \mathrm{NaCl}$} \\
\hline Roshan & $0.312 \pm 0.21$ & $0.112 \pm 0.01$ & $0.097 \pm 0.31$ & $0.006 \pm 0.04$ & $0.544 \pm 0.11$ & $3.297 \pm 0.31$ & $6.05 \pm 0.21$ & $34.2 \pm 0.03$ & $70.1 \pm .22$ \\
\hline $\begin{array}{l}\text { Super } \\
\text { Head\#2 }\end{array}$ & $0.368 \pm 0.01$ & $0.087 \pm 0.03$ & $0.053 \pm 0.02$ & $0.011 \pm 0.62$ & $2.30 \pm 0.21$ & $1.14 \pm 0.14$ & $0.49 \pm 0.02$ & $6.2 \pm 0.023$ & $61.4 \pm 0.7$ \\
\hline $\mathrm{F}_{8}$ RILs & $0.887 \pm 0.03$ & $0.352 \pm 0.01$ & $0.125 \pm 0.005$ & $0.002 \pm 0.001$ & $1.69 \pm 0.09$ & $1.05 \pm 0.031$ & $2.13 \pm 0.30$ & $31.54 \pm 0.55$ & $68.5 \pm 0.2$ \\
\hline
\end{tabular}

${ }^{1}$ Fresh weight of shoot; ${ }^{2}$ fresh weight of root; ${ }^{3} \mathrm{dry}$ weight of shoot; ${ }^{4} \mathrm{dry}$ weight of root; ${ }^{5} \mathrm{Na}$ concentration; ${ }^{6} \mathrm{~K}$ concentration; ${ }^{7} \mathrm{~K} / \mathrm{Na}$ ratio; ${ }^{8} \mathrm{chlorophyll}$ content; ${ }^{9}$ relative water content.

Significant differences $(P<0.001)$ were observed among wheat RILs for all measuring traits at seedling stage. Also, there were significant differences at $\mathrm{p}<0.05$ level between salinity treatment for all traits, except sodium concentration $(p<0.01)$. Interaction of RILs and salinity treatment were also significant (Table 1). Means for traits of all plants grown at 10 (control) and $150 \mathrm{mM} \mathrm{NaCl}$ are shown in Table 2. Under control conditions, Superhead\#2 had higher dry weight of shoot and root and sodium concentration as compared to Roshan and all the wheat RILs, but potassium concentration, $\mathrm{K}^{+} / \mathrm{Na}^{+}$ratio, chlorophyll content and RWC of Roshan were more than that of Superhead\#2.

For all RILs, fresh and dry weight of shoot and root, chlorophyll content, $\mathrm{K}^{+}$concentration and RWC decreased in response to increasing concentrations of $\mathrm{NaCl}$ to $150 \mathrm{mM}$ (Table 2), but chemical analysis of RILs indicated that sodium concentration increased under saline condition (Table 2). Roshan is a salt resistance cultivar and it showed low $\mathrm{Na}$ and high $\mathrm{K}$ concentration in salinity treatment, so this cultivar could get high 


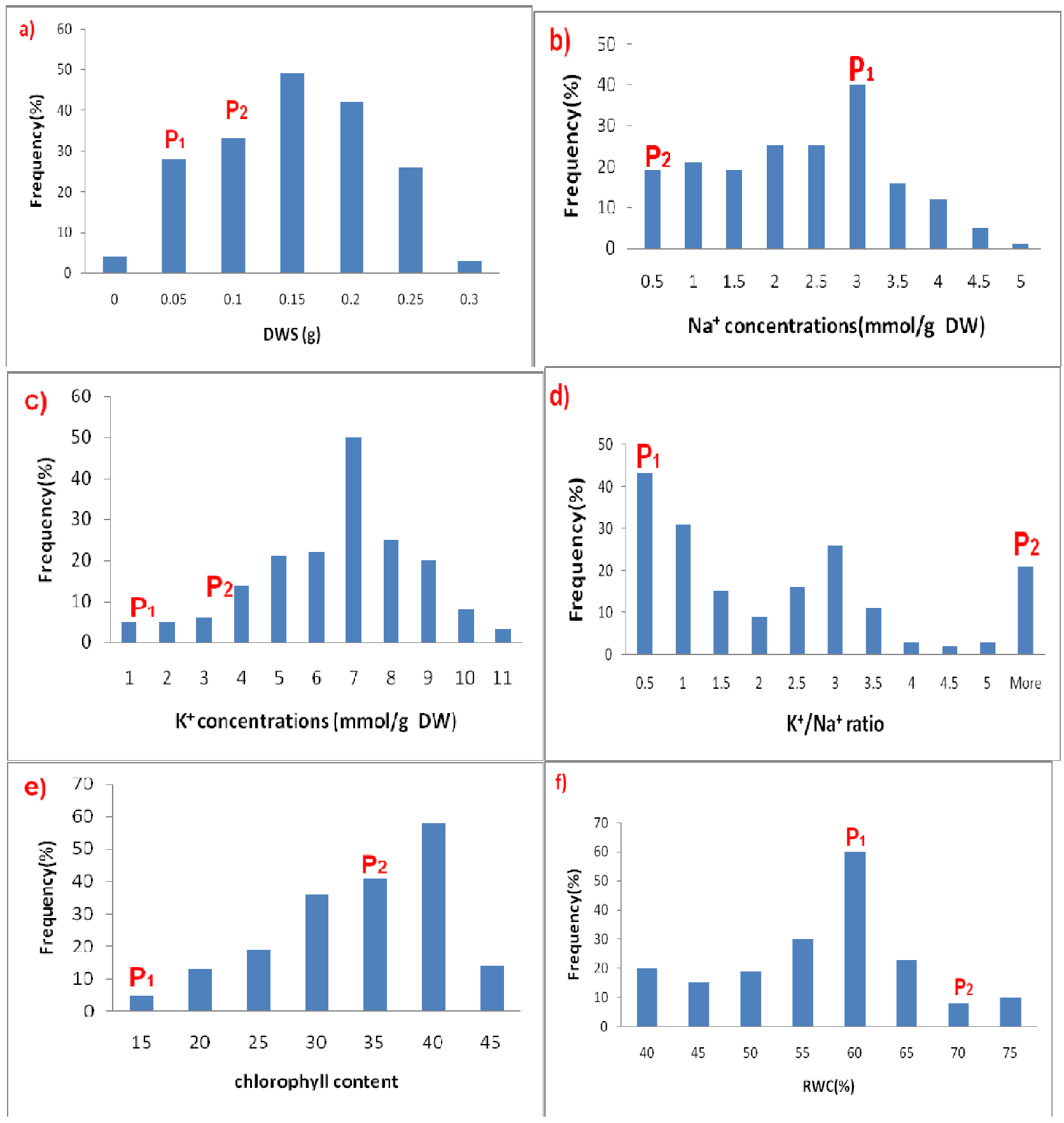

Figure 1. Frequency distribution of DWS (a), $\mathrm{Na}^{+}$and $\mathrm{K}^{+}$concentrations (b and c), $\mathrm{K}^{+} / \mathrm{Na}^{+}$ratio (d), chlorophyll content (e), RWC (f) and parents position (Superhead\#2 $=\mathrm{P}_{1}$ and Roshan $=\mathrm{P}_{2}$ ) among the $186 \mathrm{~F}_{8}$ recombinant inbred lines grown at $150 \mathrm{mM}$ $\mathrm{NaCl}$.

$\mathrm{K}^{+} / \mathrm{Na}^{+}$ratio (6.05) which is a good salinity tolerance index. This cultivar also had higher dry weight of shoot and RWC (Table 2). Frequency distribution for $\mathrm{Na}^{+}$and $\mathrm{K}^{+}$concentrations, $\mathrm{K}^{+} / \mathrm{Na}^{+}$ratio and chlorophyll content and parents position among $186 \mathrm{~F}_{8}$ recombinant inbred lines in salinity treatment showed that there were good variations among RILs, and the parents had different response under salinity stress (Figure 1 ).
On the basis of shoot dry weights, low $\mathrm{Na}$ concentration, high $\mathrm{K}^{+} / \mathrm{Na}^{+}$ratio and high RWC under saline conditions, among all RILs, we could find four RILs $(127,105,89$ and 90$)$ that had good response and showed better performance to salinity stress (Figure 2a to f). Lines 89 and 90 had very high $\mathrm{K}^{+} / \mathrm{Na}^{+}$ratio (28.4 and 28.21, respectively), low $\mathrm{Na}$ concentration (0.045 and 0.044 , respectively), high chlorophyll content, dry weight 
a)

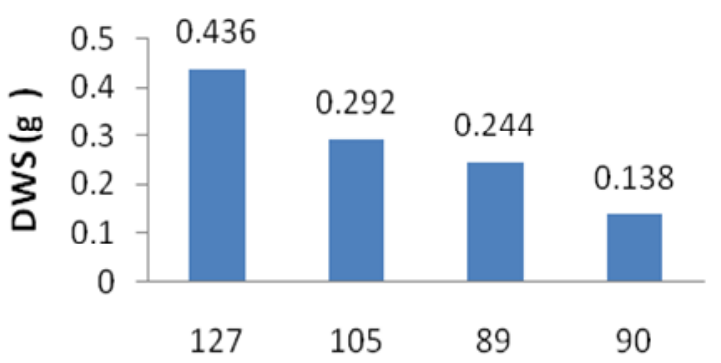

RILS No

\section{b)}

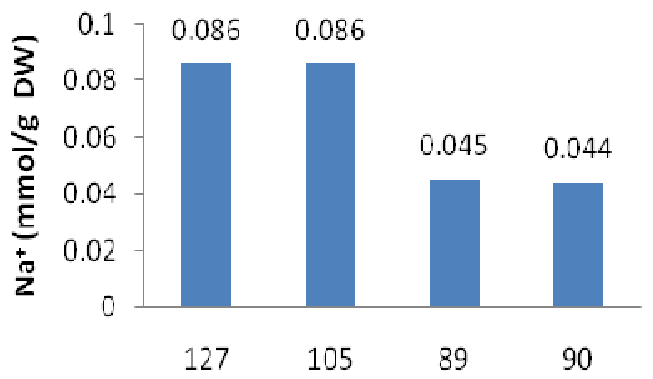

RILS No c)

LSD $=0.221$

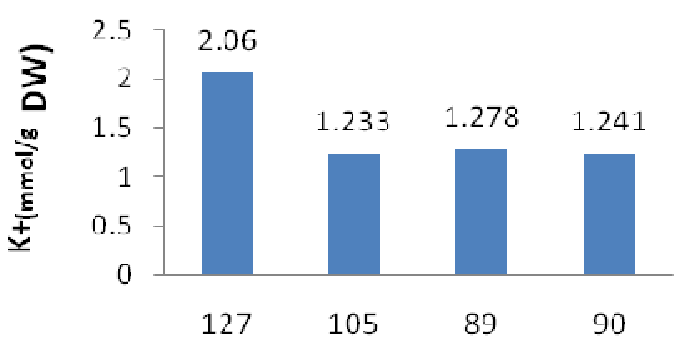

RILs No
LSD $=2.319$

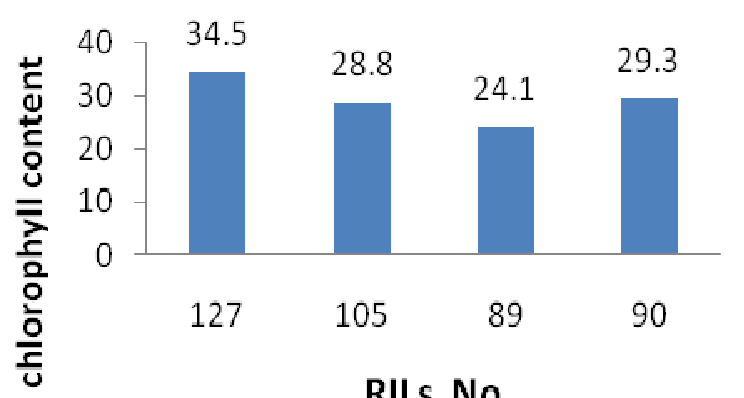

RILs No d)

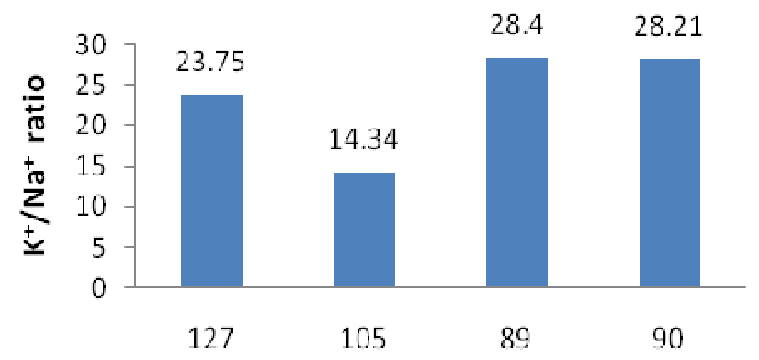

RILs No
$\mathrm{LSD}=6.84$

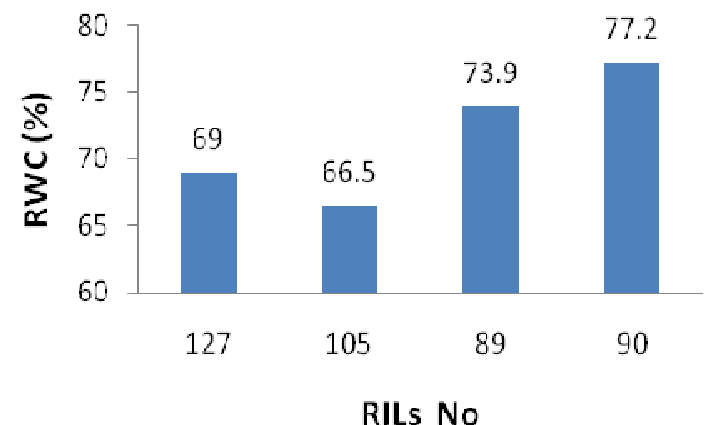

Figure 2. Four superior RILs that had high DWS, K concentration, K/Na ratio, chlorophyll content (after three weeks $150 \mathrm{mM} \mathrm{NaCl}$ treatment) and RWC (a, c, d, e and f), and low Na content (b) (after 2 weeks $150 \mathrm{mM}$ $\mathrm{NaCl}$ treatment), as compared to the others.

of shoot and RWC (Figure 2a to f).

\section{DISCUSSION}

In general, Roshan was different from Superhead\#2 for all the studied traits. This cultivar (Roshan) had the lowest leaf $\mathrm{Na}$ concentration, relatively high $\mathrm{K}$ concen- tration, and also high $\mathrm{K}^{+} / \mathrm{Na}^{+}$ratio, so it showed higher tolerance under salinity tolerance (Dashti et al., 2010) than Superhead\#2.

Plant adaptations to salinity are of three distinct types: osmotic stress tolerance, $\mathrm{Na}^{+}$exclusion and tissue tolerance. The main site of $\mathrm{Na}^{+}$toxicity for most plants is the leaf blade, so excluding $\mathrm{Na}^{+}$from the leaf blades is important (Munns and Tester, 2008). In our experiment, 
Table 3. Salinity tolerance of parents and four superior RILs in control and salinity treatment.

\begin{tabular}{|c|c|c|c|}
\hline \multirow{2}{*}{$\begin{array}{l}\text { Parents name or } \\
\text { RILs number }\end{array}$} & \multicolumn{2}{|c|}{ Shoot dry weight (g) } & \multirow{2}{*}{$\begin{array}{c}\text { Salt tolerance } \\
\text { Control (\%) }\end{array}$} \\
\hline & Control & $150 \mathrm{mM} \mathrm{NaCl}$ & \\
\hline Roshan & 0.199 & 0.097 & 48.7 \\
\hline Super head\#2 & 0.235 & 0.053 & 22.6 \\
\hline 127 & 0.571 & 0.436 & 76.3 \\
\hline 105 & 0.421 & 0.292 & 69.3 \\
\hline 89 & 0.309 & 0.244 & 78.9 \\
\hline 90 & 0.139 & 0.138 & 99.2 \\
\hline
\end{tabular}

sodium concentration increased due to salinity in both parents and $186 \quad F_{8}$ RILs. Roshan and Superhead cultivars showed 135 and $294 \%$ increase in sodium concentration, respectively; however the means of $186 \mathrm{~F}_{8}$ RILs showed $597 \%$ increase in sodium concentration. Among all RILs, minimum $\mathrm{Na}$ concentration found were for lines 90 and 89 with 0.044 and $0.045 \mathrm{mmol} / \mathrm{g} \mathrm{DW}$, respectively. Literatures reported that salt tolerance is associated with sodium concentration (Gorham et al., 1990; Munns et al., 2000). There was a significant negative correlation at the $p=0.01$ level between shoot dry matter and leaf sodium concentration $\left(r=-0.52^{* \star}\right)$ and significant positive correlation between shoot dry matter and leaf $\mathrm{K}^{+}$concentration $\left(r=0.47^{* *}\right)$ under salinity stress. A significant negative correlations between leaf sodium concentration and shoot dry matter (Munns et al., 2006), salt tolerance index (STI) (Goudarzi and Pakniyat, 2008), grain yield (Goudarzi and Pakniyat, 2008) and salt tolerance (shoot dry biomass in salt treatment as percentage of biomass in control treatment) (Munns, 2005) have been reported in literatures. In general, the genotypes with the lowest $\mathrm{Na}^{+}$concentrations produced the greatest dry matter. These low- $\mathrm{Na}^{+}$genotypes had fewer injured leaves, and a greater proportion of living to dead leaves (Munns et al., 2006).

The concentration of $\mathrm{K}^{+}$in the cytoplasm in relation to that of $\mathrm{Na}^{+}$may be a contributing factor to salinity tolerance (Munns and Tester, 2008). Potassium concentration of parents $\left(P_{2}\right.$ and $\left.P_{1}\right)$ and RILs decreased due to the increasing salinity $(8,60$ and $37 \%$, respectively).

High levels of $\mathrm{Na}^{+}$inhibit the $\mathrm{K}^{+}$uptake and as a result of this, it causes a decrease in the $\mathrm{K}^{+} / \mathrm{Na}^{+}$ratio. Four superior RILs (90, 89, 127 and 105) showed low $\mathrm{Na}$ and high $\mathrm{K}$ concentration in salinity treatment, so these lines got high $\mathrm{K}^{+} / \mathrm{Na}^{+}$ratio (after two weeks of $150 \mathrm{mM} \mathrm{NaCl}$ treatment), when compared with the others.

Munns et al. (2006) reported that the high $\mathrm{Na}^{+}$lines lost chlorophyll more rapidly and died earlier than the low $\mathrm{Na}^{+}$ lines. After three weeks of $150 \mathrm{mM} \mathrm{NaCl}$ treatment, chlorophyll content of these four lines was greater than that of the others.

RWC represents a useful indicator of the state of water balance of a plant (González and González-Vilar, 2001), and has been widely accepted as a reproducible and meaningful index of plant water status (Smart, 1974).
Many physiological processes, such as leaf photosynthesis are directly affected by loss of water from leaf tissue. So on the basis of our results, it can be used as a screening tool for salinity tolerance in wheat lines.

Correlations between shoot dry matter and $\mathrm{K}^{+} / \mathrm{Na}^{+}$ratio, chlorophyll content and RWC was significantly positive ( $r$ $=0.36^{\star *}, r=0.20^{\star *}$ and $r=0.39^{\star *}$, respectively). Table 3 shows the salinity tolerance of the parents and four superior RILs in the control and $150 \mathrm{mM} \mathrm{NaCl}$. RILs 90 , 89,127 and 105 showed on average 99, 78, 76 and 69\% of the control shoot dry weight at salinity treatment, respectively, as compared with salt tolerance parent (Roshan) with $48 \%$.

The behavior of the four lines during salinity treatment showed that these lines could be introduced as salinity tolerance and use for future experiments and also in wheat lines $\mathrm{K}^{+} / \mathrm{Na}^{+}$ratio (Zhu et al., 2001; Goudarzi and Pakniyat, 2008; Thalji and Shalaldeh, 2007), sodium exclusion (Munns, 2005), chlorophyll content and RWC could be considered as salinity indexes for salt tolerant under saline condition.

\section{ACKNOWLEDGEMENT}

This research was supported by the Agricultural Biotechnology Research Institute of Iran (ABRII).

\section{REFERENCES}

Asch F, Dingkuhn M, Dorffling K, Miezan K (2000). Leaf K/Na ratio predicts salinity induced yield loss in irrigated rice. Euphytica, 113 : 109-118.

Ashraf M, O'Leary JW (1986). Responses of some newly developed salt-tolerant genotypes of spring wheat to salt stress: 1. Yield components and ion distribution. J. Agron. Crop Sci. 176(2): 91-101.

Barrs HD, Weatherley PE (1962). A re-examination of the relative turgidity technique for estimating water deficits in leaves. Aust. J. Biol. Sci. 24: 519-570.

Bartels D, Sunkar R (2005).Drought and Salt Tolerance in Plants. Crit. Rev. Plant Sci., 24: 23-58.

Chen Z, Newman I, Zhou M, Mendham N, Zhang G, Shabala S (2005). Screening plants for salt tolerance by measuring $\mathrm{K}^{+}$flux: a case study for barley. Plant, Cell Environ. 28:1230-1246.

CISEAU, IPTRID, AGLL, FAO (2005). Management of irrigation-induced salt affected soils. avalable at: $\mathrm{ftp} / / / \mathrm{ftp} . f a o . o r g / a g l / a g l l /$ docs/salinity brochure eng.pdf.

Dasgan HH, Aktas H, Abak K, Cakmak I (2002). Determination of 
screening techniques to salinity tolerance in tomatoes and investigation of genotype responses. Plant sci. 163 (4): 695-703.

Dashti H, Naghavi MR, Tajabadipour A (2010).Genetic Analysis of Salinity Tolerance in a Bread Wheat Cross. J. Agric. Sci. Tech. 12: 347-356.

Din J, Khan SU, Ali I (2008). Physiological response of wheat (Triticum aesitivum L.) varieties as influenced by salinity stress. J. Anim. Plant Sci. 18(4):125-129.

Dubcovsky J, Santa María G, Epstein E, Luo MC, Dvořák J (1996). Mapping of the $\mathrm{K}^{+} / \mathrm{Na}^{+}$discrimination locus Kna1 in wheat .Theor. Appl. Gene. 92:448-454.

$\mathrm{FAO}$, land and plant nutrition management. problem soil database. (2000). http://www.fao.org/ag/AGL/agll/prosoil/salt.htm.

Flowers T, Yeo A (1995). Breeding for salinity resistance in crop plants: where next? Aust. J. Plant Physiol. 22:875-884.

Garcia A, Senadhira D, Flowers TJ, Yeo AR (1995). The effects of selection for sodium transport and of selection for agronomic characteristics upon salt resistance in rice (Oryza sativa L.). Theor. Appl. Genet . 90: 1106-1111.

Genc Y, McDonald GK, Tester M (2007). Reassessment of tissue Na+ concentration as a criterion for salinity tolerance in bread wheat. Plant Cell Environ. 30: 1486-1498.

González L, González-Vilar M (2001).Determination of relative water content. In: Handbook pl. ecophysiol. technique. Springer. Netherland, ISBN: 978-0-7923-7053-6, pp. 207-212.

Goudarzi M, Pakniyat H (2008). Evaluation of wheat cultivars under salinity stress based on some agronomic and physiological traits. J. Agric. Soc. Sci. 4: 35-38.

Gorham J (1989). Salt Tolerance in the Triticeae: K/Na Discrimination in Aegilops Species. J. Exp. Bot. 41(5): 615-621.

Gorham J, Wyn Jones RG, Bristol A (1990). Partial characterization of the trait for enhanced $\mathrm{K}+-\mathrm{Na}+$ discrimination in the $\mathrm{D}$ genome of wheat. Planta, 180: 590-597.

Gregorio GB, Senadhire D, Mendoza RD (1997). Screening rice for salinity tolerance.IRRI discussion paper series no.22.Manila(Philippines):International Rice Research Inistitute.

Hoagland DR, Arnon DI (1950). The water culture method for growing plants without soil. California Agric. Exp. Station Circular, 347: 1-32.

Khan AA, McNelly T, Azhar FM (2001). Stress tolerance in crop plants. Int. J. Agric. Biol. 2: 250-255.

Ma L, Erfend Z, Naxing H, Ronghua Z, Guoying W, Jizeng J (2007). Genetic analysis of salt tolerance in recombinant inbred population of wheat (Triticum aestivem L.) Euphytica. 153:109-117.

Mahajan M, Tuteja N (2005). Cold, salinity and drought stresses: An overview. Archives Biochem. Biophys. 444: 139-15. 444:139-158.

Møller IS, Tester M (2007). Salinity tolerance of Arabidopsis: a good model for cereals?. Trends Plant Sci. pp. 12- 12.

Munns R (2005). Genes and salt tolerance: bringing them Together. New Physiologist, 167: 645-663.

Munns R, James RA (2003). Screening methods for salinity tolerance: a case study with tetraploid wheat. Plant Soil, 253: 201-218.
Munns R, Rebetzke GJ, Husain S, James RA, Hare RA (2003). Genetic control of sodium exclusion in durum wheat. Aust. J. Agric. Res. 54: 627-635.

Munns R, Tester M (2008). Mechanisms of salinity tolerance. Annu. Rev. Plant Biol. 59: 651-681.

Munns R, James RA, La" uchli A (2006). Approaches to increasing the salt tolerance of wheat and other cereals. J. Exp. Bot. 57(5): 102501043.

Munns R, Hare RA, James RA, Rebetzke GJ (2000). Genetic variation for improving the salt tolerance of durum wheat. Aust. J. Agric. Res. 51: 69-74.

Neumann P (1997). Salinity resistance and plant growth revisited. Plant Cell Environ. 20:1193-1198.

Peel MD, Waldron BL, Jensen KB, Chatterton NJ, Horton H, Lynn M (2004). Screening for Salinity Tolerance in Alfalfa: A Repeatable Method. Crop Sci. 44: 2049-2053.

Pritchard DJ, Hollington PA, Davies WP, Gorham J, Diaz DE, Leon JL, Mujeeb-Kazi A (2002). $\mathrm{K}_{+} / \mathrm{Na}_{+}$discrimination in synthetic hexaploid wheat lines: Transfer of the trait for $\mathrm{K}_{+} / \mathrm{Na}_{+}$discrimination from Aegilops tauschii into a Triticum turgidum background. Cereal Res. Commun., 30: 261-267.

Rengasamy P (2006). World salinization with emphasis on Australia. J. Exp. Bot. 57(5):1017-1023.

Sairam RK, Tyagi A (2004). Physiology and molecular biology of salinity stress tolerance in plants. Curr. Sci. 86- 386:407-421

Shannon MC (1997). Adaptation of plants to salinity. United States Department of Agriculmre. Agricultural Research Service. U.S Salinity Laboratory.

Shaterian J, Waterer DR, Jong H, Tanino KK (2008). Methodologies and Traits for Evaluating the Salt Tolerance in Diploid Potato Clones. Am. J. Pot Res., 85: 93-100.

Smart RE (1974). Rapid Estimates of Relative Water Content. Plant Physiol. 53: 258-260.

Sohail M, Saied AS, Gebauer J, Buerkert A (2009). Effect of $\mathrm{NaCl}$ Salinity on Growth and Mineral Composition of Ziziphus spina-christi (L.) Willd. J. Agric. Rural Dev. Tropics Subtropics, 110(2): 107-114.

Thalji T, Shalaldeh G (2007).Screening wheat and barley genotype for salinity resistance. J. Agron. 6(1): 75-78.

USSL (2005). George E. Brown Jr. Salinity Laboratory. Riverside, CA, USA: USDA-ARS. http://www.ussl.ars.usda.gov.

Vysotskaya L, Hedley PE, Sharipova G, Veselov D, Kudoyarova G, Morris J, Jones HG (2010). Effect of salinity on water relations of wild barley plants differing in salt tolerance. AoB Plants Vol. 2010. 86:407421

Zhu GY, Kinet JM, Lutts S (2001). Characterisation of rice (Oryza sativa L.) F3 populations selected for salt resistance. I. Physiological behaviour during vegetative growth. Euphytica, 121: 25-263. 